\title{
Activity of phytate dephosphorylation in cereals, legumes and oilseeds determined by colourimetric and isotachophoretic method*
}

\author{
M. Marounek ${ }^{1,2,4}$, I. Bubancová ${ }^{2}$, M. Podsedníček ${ }^{2}$, D. Lukešová ${ }^{3}$ \\ and M.A. Ramadan ${ }^{1}$ \\ ${ }^{1}$ Czech Academy of Sciences, Institute of Animal Physiology and Genetics \\ CZ-142 20 Prague, Czech Republic \\ ${ }^{2}$ Institute of Animal of Science \\ CZ-104 00 Prague, Czech Republic \\ ${ }^{3}$ Czech University of Life Sciences, Institute of Tropics and Subtropics \\ CZ-165 21 Prague, Czech Republic
}

(Received 6 January 2011; revised version 16 July 2011; accepted 11 August 2011)

\begin{abstract}
Activity of phytate dephosphorylation was determined in 26 samples of cereals, legumes, oilseeds and complete diets for poultry using the colourimetric and isotachophoretic method. The former method was based on the colour formed upon the reaction of molybdate with phosphate released from phytate. The latter method was based on measurement of decrease of phytate concentration in the reaction mixture. Rye had by far the highest phytate dephosphorylation activity, followed by wheat and wheat-containing diets. However, for most of the other samples, this activity was low. Phytate dephosphorylation activity as measured by capillary isotachophoresis was numerically lower than activity measured using the molybdate method; however, activities assayed by both methods correlated with statistical significance $(\mathrm{r}=0.86 ; \mathrm{P}<0.001)$. The isotachophoretic method may be suitable for phytate dephosphorylation activity assay in feeds with a high content of inorganic phosphate and in samples of digesta and faeces.
\end{abstract}

KEY WORDS: phosphorus, phytate, dephosphorylation, phytase, feeds

\footnotetext{
* Supported by the Czech Science Foundation, Project No. 525/08/H060

M.A. Ramadan is the research assistant by Dairy Department of the National Research Centre in Cairo, Egypt

${ }^{4}$ Corresponding author: e-mail: marounek@iapg.cas.cz
} 


\section{INTRODUCTION}

Myo-inositol-hexakisphosphate, or phytate, is the main storage form of phosphorus $(\mathrm{P})$ in plant seeds. Phytate $\mathrm{P}$ is relatively unavailable in monogastric animals due to insufficient endogenous phytase activity in the digestive tract. To improve the availability of phytate $\mathrm{P}$, diets of poultry and pigs are often supplemented with phytases of microbial origin (Selle and Ravindran, 2007, 2008). Some plant feedstuffs such as wheat and rye contain powerful phytases capable of hydrolysing phytate within the animal digestive tract. Literature data on effect of intrinsic phytase activity of feeds on phytate digestibility are ambiguous. It has been shown in pigs (Leytem and Thacker, 2008) and chickens (Leytem et al., 2008) that the total tract phytate degradation was not related to the level of endogenous phytase in the diet. On the contrary, Schlemmer et al. (2001) concluded that plant phytases were responsible for the degradation of inositol phosphates in the pig stomach and Oloffs et al. (2000) reported a significant correlation between intrinsic phytase activity of feedstuffs and phosphorus utilization in hens. According to Pallauf and Rimbach (1997), the utilization of phytate phosphorus can be considerably increased by feed components such as rye, triticale, wheat and barley, i.e. by feeds with high phytase activity. In experiment of Zimmermann et al. (2002), however, cereal phytases were less efficient in pigs than microbial Natuphos ${ }^{\circledR}$ phytase as $2.5 \mathrm{U}$ of cereal phytase from wheat or rye were needed to replace $1 \mathrm{U}$ of microbial phytase. This was probably caused by a negative effect of low $\mathrm{pH}$, pepsin and pancreatin in the gastrointestinal tract on the intrinsic activity of grains. In contrast, stability of Aspergillus niger phytase was not much influenced by a low $\mathrm{pH}$ and the presence of pepsin and pancreatin (Phillippy, 1999).

The determination of phytate dephosphorylation ('phytase') activity is usually based on the colour that is formed upon the reaction of molybdate with the $\mathrm{P}_{\mathrm{i}}$ released from phytate (Cooper and Goving, 1983; Eeckhout and De Paepe, 1994; Engelen et al., 2001). This method is inaccurate when this activity is measured in samples containing water-soluble phosphates because the high background of $\mathrm{P}$ decreases the colour contribution by the enzymatic hydrolysis of phytate. To avoid this problem, Schlemmer et al. (2001) elaborated a method based on phytase protein precipitation and subsequent removal of inorganic phosphate by dialysis. An improved colourimetric method for the rapid determination of phytase activity in feeds was developed by Kim and Lei (2005). This method uses a spin column to remove free phosphate before measuring phytase activity. The measurement of phytate degradation to lower inositol phosphates and $\mathrm{P}_{\mathrm{i}}$ using a suitable chromatographic or electrophoretic technique represents another way of assessment of the phytate dephosphorylation activity. In the present study, the levels of phytate $\mathrm{P}$ and phytate dephosphorylation activity were determined in samples of 
cereals, legumes, oilseeds and complete diets for poultry containing wheat, maize and soyabean or maize and soyabean. Two methods of phytate dephosphorylation activity measurement were used: the method of Eeckhout and De Paepe (1994) based on the colourimetric assay, and the capillary isotachophoretic method.

\section{MATERIAL AND METHODS}

\section{Samples}

A total of 26 samples representing cereals, legumes, oilseeds and complete diets for poultry were collected and analysed for total $\mathrm{P}$, phytate $\mathrm{P}$ and phytate dephosphorylation activity. All measurements were carried out in duplicate. The wheat-maize-soyabean diet for laying hens contained wheat, maize, soyabean meal (extracted) and wheat bran at 353,303, 155 and $26 \mathrm{~g} / \mathrm{kg}$, respectively. The maize-soyabean diet for laying hens contained maize, soyabean meal and rapeseed meal at 593, 205 and $75 \mathrm{~g} / \mathrm{kg}$, respectively. Both diets were supplemented with dicalcium phosphate to increase total P concentration from 5.94 to $8.02 \mathrm{~g} / \mathrm{kg} \mathrm{DM}$, and from 4.52 to $7.20 \mathrm{~g} / \mathrm{kg} \mathrm{DM}$ in the former and latter diets, respectively.

\section{Phosphorus and phytate P determination}

Total phosphorus in feeds was determined by a vanadomolybdate reagent after ashing dry samples at $550^{\circ} \mathrm{C}(\mathrm{AOAC}, 2005)$. Phytic acid was extracted from finely ground feeds by $0.95 \mathrm{M} \mathrm{HCl}$, and content was determined by the isotachophoretic method (Dušková et al., 2001).

\section{Phytate dephosphorylation activity determination by the colourimetric method}

Phytase activity was measured as described by Eeckhout and De Paepe (1994). Briefly, $0.2 \mathrm{~g}$ of each finely ground sample was weighed in a $50 \mathrm{ml}$ volumetric flask, which was then filled with a solution of $1.5 \mathrm{mM}$ Na-phytate in $0.25 \mathrm{M}$ acetate buffer, $\mathrm{pH}$ 5.5. The flasks were shaken for $15 \mathrm{~min}$ and then placed in a water bath at $37^{\circ} \mathrm{C}$. After $10 \mathrm{~min}$, a portion of the incubate $(2 \mathrm{ml})$ was placed in a test tube, and the same volume of $10 \%$ trichloroacetic acid was added to stop the reaction. After another $60 \mathrm{~min}$, the procedure was repeated. The contents of both tubes were centrifuged $(5000 \mathrm{~g}, 10 \mathrm{~min})$, and the concentration of $\mathrm{P}_{\mathrm{i}}$ in the supernatant was determined using the acid molybdate reagent (Peterson, 1978). Colour was measured in a spectrophotometer at $700 \mathrm{~nm}$ and compared with a calibration series containing $1 \mathrm{ml}$ of $10 \%$ trichloroacetic acid per cuvette, $1 \mathrm{ml}$ of phosphate standard solution $(0,10,20,30$ or $40 \mu \mathrm{mol} / \mathrm{ml})$ and $2 \mathrm{ml}$ of 
colour reagent. The increased concentration of $\mathrm{P}_{\mathrm{i}}$ during the 60 min incubation was attributed to phytate dephosphorylation activity. A unit of this activity (U) is defined as the activity that liberates $\mathrm{P}_{\mathrm{i}}$ at a rate of $1 \mu \mathrm{mol} / \mathrm{min}$.

\section{Phytase activity determination by the isotachophoretic method}

To measure phytate dephosphorylation activity by the isotachophoretic method, finely ground samples $(3 \mathrm{~g})$ were weighed into $50 \mathrm{ml}$ flasks, and $30 \mathrm{ml}$ of acetate buffer ( $\mathrm{pH} \mathrm{6.5)}$ ) were added. Flasks were shaken for $15 \mathrm{~min}$, and a $2 \mathrm{ml}$ aliquot was removed and frozen. Two millilitres of $30 \mathrm{mM}$ Na-phytate (cat. no. P 3168, Sigma-Aldrich Ltd., Prague, Czech Republic) were added to increase the phytate concentration by $2 \mathrm{mM}$. The mixture was incubated in a shaking water bath at $37^{\circ} \mathrm{C}$ for $60 \mathrm{~min}$. At the end of the incubation, $4 \mathrm{ml}$ samples of the incubation fluid were removed and heated at $100^{\circ} \mathrm{C}$ for 4 min to stop the enzyme reaction. Samples were stored at $-20^{\circ} \mathrm{C}$ until analysis. Phytate contents of samples from the beginning and the end of the incubation were determined by capillary isotachophoresis (Dušková et al., 2001), except that the Fe precipitation step was omitted. The samples were thawed and centrifuged $(5000 \mathrm{~g}, 10 \mathrm{~min})$, and supernatants were analysed with a column-coupling instrument EA 101 (Villa Labeco Comp., Slovakia). The phytate zone was identified by step height using a standard solution. Quantitative estimation of phytate was made via a regression equation between the concentration of phytate in extracts and the zone length. An external calibration method was used with solutions of the dodecasodium salt of phytic acid as standards. Seven calibration points were measured in the concentration range from 10 to $120 \mu \mathrm{M}$. The decrease of phytate concentration during the $60 \mathrm{~min}$ incubation was attributed to phytate dephosphorylation activity. Phytate dephosphorylation activity (U') is defined as the activity that degrades phytic acid at a rate of $1 \mathrm{~mol} / \mathrm{min}$.

\section{Other assays}

In a sample of the feed mixture for poultry based on wheat, maize and soyabean, the phosphate present in the reaction mixture was determined eight times to assess the variability of the colourimetric phosphate assay. Corresponding measurements of phytate concentration were performed before and after the enzyme reaction by the isotachophoretic method.

To follow the effect of phytase addition on residual phytate concentration in the reaction mixture, a commercial phytase (Natuphos, $10.000 \mathrm{U} / \mathrm{kg}$; BASF) was suspended in distilled water and added to the reaction mixture containing ground oats at $0,3,6,15$ and $30 \mathrm{U}$. The reaction mixture was incubated as described above, and the residual phytate was determined by the isotachophoretic method. 


\section{RESULTS AND DISCUSSION}

All enzyme assays measure either the consumption of substrate or the production of a product over time. The isotachophoretic method for determining phytate dephosphorylation activity is based on estimating the degradation of phytic acid to lower inositol phosphates. The phytic acid molecule contains six phosphate groups, thus data on phytate dephosphorylation activity are numerically higher using the colourimetric method. Furthermore, phosphates released from various compounds by phosphatases probably participate in the colour formation. However, a significant correlation was found between activities determined using these methods $(\mathrm{r}=0.86 ; \mathrm{P}<0.001)$. In agreement with Eeckhout and De Paepe (1994), no relationship can be established between phytate dephosphorylation activity and total $\mathrm{P}$ or phytate $\mathrm{P}$ content. An almost linear relationship was found between added fungal phytase and residual phytate in the reaction mixture across a wide range of phytate concentrations (Figure 1). Figure 1 shows that phytate was not rate limiting above $0.25 \mu \mathrm{mol} / \mathrm{ml}$, and that the range 0.5 to $2.0 \mu \mathrm{mol} / \mathrm{ml}$ is optimum for routine phytate dephosphorylation activity determinations.

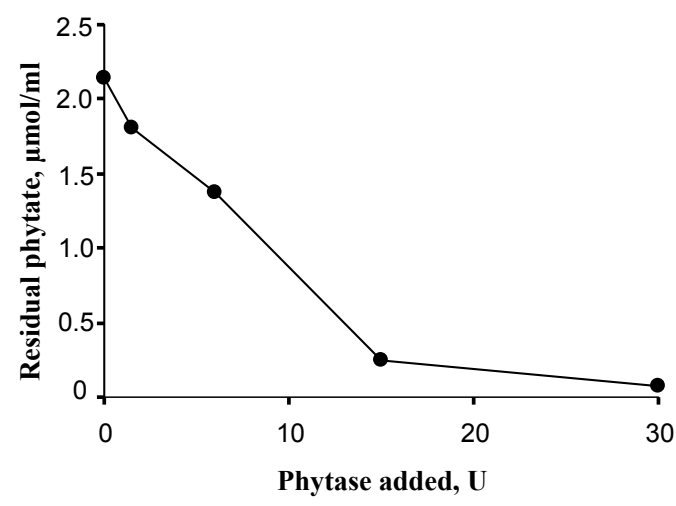

Figure 1. The effect of supplemental phytase added to a reaction mixture containing oats, physiological saline and Na-phytate on residual phytate after $60 \mathrm{~min}$ incubation. Residual phytate was determined by the isotachophoretic method

Both methods gave similar coefficients of variation for multiple assays of phosphate and phytate concentration in the reaction mixtures containing the same sample. The concentrations of phosphate at the beginning and end of the reaction were $238 \pm 11 \mu \mathrm{mol} / 1(\mathrm{CV}=4.62 \%)$ and $402 \pm 12 \mu \mathrm{mol} / 1(\mathrm{CV}=3.00 \%)$, respectively. Corresponding concentrations of phytate were $2.26 \pm 0.07 \mathrm{mmol} / 1(\mathrm{CV}=3.10 \%)$ and $0.68 \pm 0.03 \mathrm{mmol} / \mathrm{l}(\mathrm{CV}=4.41 \%)$, respectively. The $\mathrm{pH}$ of the acetate buffer used in the isotachophoretic method was increased to 6.5, which may be different from the optimum $\mathrm{pH}$ for plant phytases, but is more similar to the $\mathrm{pH}$ of the digestive 
tract of poultry. In chickens fed a wheat-based diet, the $\mathrm{pH}$ values of the digesta in the crop, the anterior small intestine and the posterior small intestine were 6.30, 6.50 and 7.27, respectively. Similar $\mathrm{pH}$ values have been reported in chickens fed a rye-based diet (Boros et al., 1998). However, buffers of different $\mathrm{pH}$ values may be used depending on the specific situation.

Phytate $\mathrm{P}$ content as a percentage of total $\mathrm{P}$ in cereals, grain legumes and oilseeds varies from $>40$ to $85 \%$ (reviewed by Ravindran et al., 1995). In samples examined in the present study, phytate $\mathrm{P}$ as a percentage of total $\mathrm{P}$ was highest in white lupin (82.6\%) and lowest $(24.9 \%)$ in the maize-soyabean feed mixture supplemented with $20 \mathrm{~g} / \mathrm{kg}$ dicalcium phosphate (Table 1 ). Rye, wheat bran, wheat

Table 1. Total phosphorus (P), phytate $\mathrm{P}$ and phytate dephosporylation activity of cereals, oilseeds, legumes and feed mixtures determined by the colourimetric and isotachophoretic method

\begin{tabular}{|c|c|c|c|c|c|}
\hline \multirow{3}{*}{ Sample } & \multirow{3}{*}{$\begin{array}{l}\text { Total P } \\
\text { g/kg DM }\end{array}$} & \multirow{2}{*}{\multicolumn{2}{|c|}{ Phytate P }} & \multicolumn{2}{|c|}{ Phytate dephosphorylation activity } \\
\hline & & & & \multirow{2}{*}{$\begin{array}{l}\text { colourimetric } \\
\text { method } \mathrm{U} / \mathrm{kg}^{1}\end{array}$} & \multirow{2}{*}{$\begin{array}{l}\text { isotachophoretic } \\
\text { method } U^{\prime} / \mathrm{kg}^{2}\end{array}$} \\
\hline & & $\mathrm{g} / \mathrm{kg} \mathrm{DM}$ & total P \% & & \\
\hline Wheat & 3.34 & 2.01 & 60.2 & 1137 & 180 \\
\hline Barley & 3.61 & 1.81 & 50.1 & 840 & 47 \\
\hline Rye & 3.11 & 2.49 & 80.1 & 2114 & 208 \\
\hline Oats & 3.90 & 1.34 & 34.4 & 61 & 56 \\
\hline Maize & 2.51 & 2.01 & 80.1 & 282 & 10 \\
\hline Wheat bran & 11.2 & 7.83 & 70.0 & 1395 & 92 \\
\hline Buckwheat & 5.22 & 1.81 & 34.7 & 95 & 4 \\
\hline Millet & 4.19 & 1.90 & 45.3 & 269 & 21 \\
\hline Quinoa (Colombia) & 5.02 & 1.35 & 26.9 & 941 & 147 \\
\hline Quinoa (Bolivia) & 4.65 & 1.61 & 34.6 & 503 & 117 \\
\hline Sorghum & 3.38 & 2.37 & 70.1 & 265 & 11 \\
\hline Rice (short-grain) & 3.48 & 2.34 & 67.2 & 292 & 20 \\
\hline Soyabean meal & 8.91 & 3.72 & 41.8 & 150 & 12 \\
\hline Sunflower meal & 9.17 & 4.20 & 45.8 & 431 & 18 \\
\hline Rapeseed & 7.28 & 3.25 & 44.6 & 331 & 20 \\
\hline Linseed & 5.58 & 4.12 & 73.8 & 100 & 17 \\
\hline Pea & 5.48 & 2.77 & 50.5 & 200 & 29 \\
\hline Lupin white (cv. Amiga) & 4.65 & 3.84 & 82.6 & 111 & 10 \\
\hline Beans & 4.57 & 1.66 & 36.3 & 69 & 45 \\
\hline Lentil & 4.61 & 1.97 & 42.7 & 161 & 20 \\
\hline \multicolumn{6}{|l|}{ Feed mixture } \\
\hline wheat-maize-soyabean & 5.94 & 3.06 & 51.5 & 1152 & 114 \\
\hline wheat-maize-soyabean & 6.67 & 3.33 & 49.9 & 1127 & 166 \\
\hline wheat-maize-soyabean & 8.02 & 3.53 & 44.0 & 760 & 146 \\
\hline maize-soyabean & 4.52 & 1.76 & 38.9 & 181 & 16 \\
\hline maize-soyabean & 5.17 & 1.76 & 34.0 & 127 & 9 \\
\hline maize-soyabean & 7.20 & 1.79 & 24.9 & 151 & 10 \\
\hline
\end{tabular}

phytate dephosphorylation activity (U) is defined as the activity that liberates inorganic phosphate at a rate of $1 \mu \mathrm{mol} / \mathrm{min}$

2 phytate dephosphorylation activity (U') is defined as the activity that degrades $1 \mu$ mol phytic acid/min 
and feed mixtures containing wheat had the highest phytate dephosphorylation activity among tested feedstuffs $(2114,1395,1137$ and 760-1152 U/kg DM, respectively).

\section{CONCLUSIONS}

In conclusion, the isotachophoretic method represents another way of assessment of phytate dephosphorylation activity in feeds with low activity and high $\mathrm{P}_{\mathrm{i}}$ content, as well as in digesta and faecal samples, as shown in previous studies with rabbits (Marounek et al., 2003) and hens (Marounek et al., 2008, 2010). A simple and accurate assay for phytate dephosphorylation activity in feed and digesta samples is needed for research and the formulation of diets low in phosphorus. A proper activity assay is also needed to quantify the destruction of ezymic activity by the pelleting process or by heat treatment of feed. The isotachophoretic method is more laborious than the colourimetric method. Typically, 6 assays of phytate dephosphorylation activity can be carried out in $8 \mathrm{~h}$ using the isotachophoretic method but 30 using the colourimetric assay. Thus, there is no need to use the former method for activity determination in common feeds except those with low phytate dephosphorylation activity and high content of inorganic phosphates.

\section{REFERENCES}

AOAC, 2005. Association of Official Analytical Chemists, Official Methods of Analysis. $18^{\text {th }}$ Edition. Gaithersburg, MD

Boros D., Marquardt R.R., Guenter W., 1998. Site of exoenzyme action in gastrointestinal tract of broiler chicks. Can. J. Anim. Sci. 78, 599-602

Cooper J.R., Gowing H.S., 1983. A method for estimating phosphate in the presence of phytate and its application to determination of phytase. Anal. Biochem. 132, 285-287

Dušková D., Marounek M., Březina P., 2001. Determination of phytic acid in feeds and faeces of pigs and poultry by capillary isotachophoresis. J. Sci. Food Agr. 81, 36-41

Eeckhout W., De Paepe M., 1994. Total phosphorus, phytate phosphorus and phytase activity in plant feedstuffs. Anim. Feed Sci. Tech. 47, 19-29

Engelen A.J., van der Heeft F.C., Randsdorp P.H.G., Somers W.A.C., Schaefer J., van der Vat B.J.C., 2001. Determination of phytase activity in feed by a colorimetric enzymatic method: Collaborative interlaboratory study. J. AOAC Int. 84, 629-633

Kim T.W., Lei X.G., 2005. An improved method for a rapid determination of phytase activity in animal feed. J. Anim. Sci. 83, 1062-1067

Leytem A.B., Thacker P.A., 2008. Fecal phosphorus excretion and characterization from swine fed diets containing a variety of cereal grains. J. Anim. Vet. Adv. 7, 113-120

Leytem A.B., Willing B.P., Thacker P.A., 2008. Phytate utilization and phosphorus excretion by broiler chickens fed diets containing cereal grains varying in phytate and phytase content. Anim. Feed Sci. Tech. 146, 160-168 
Marounek M., Dušková D., Skřivanová V., 2003. Hydrolysis of phytic acid and its availability in rabbits. Brit. J. Nutr. 89, 287-294

Marounek M., Skřivan M., Dlouhá G., Břeňová N., 2008. Availability of phytate phosphorus and endogenous phytase activity in the digestive tract of laying hens 20 and 47 weeks old. Anim. Feed Sci. Tech. 146, 353-359

Marounek M., Skřivan M., Rosero O., Rop O., 2010. Intestinal and total tract phytate digestibility and phytase activity in the digestive tract of hens fed a wheat-maize-soyabean diet. J. Anim. Feed Sci. 19, 430-439

Oloffs K., Cossa J., Jeroch H., 2000. Phosphorus utilization from different vegetable feedstuffs by laying hens. Arch. Geflügelk. 64, 24-28

Pallauf J., Rimbach G., 1997. Nutritional significance of phytic acid and phytase. Arch. Anim. Nutr. 50, 301-319

Peterson G.L., 1978. A simplified method for analysis of inorganic phosphate in the presence of interfering substances. Anal. Biochem. 84, 164-172

Phillippy B. Q., 1999. Susceptibility of wheat and Aspergillus niger phytases to inactivation by gastrointestinal enzymes. J. Agr. Food Chem. 47, 1385-1388

Ravindran V., Bryden W.L., Kornegay E.T., 1995. Phytates: occurrence, bioavailability and implications in poultry nutrition. Poult. Avian Biol. Rev. 6, 125-143

Selle P.H., Ravindran V., 2007. Microbial phytase in poultry nutrition. Anim. Feed Sci. Tech. 135, $1-41$

Selle P.H., Ravindran V., 2008. Phytate-degrading enzymes in pig nutrition. Livest. Sci. 113, 99122

Schlemmer U., Jany K.-D., Berk A., Schulz E., Rechkemmer G., 2001. Degradation of phytate in the gut of pigs - pathway of gastrointestinal inositol phosphate hydrolysis and enzymes involved. Arch. Anim. Nutr. 55, 255-280

Zimmermann B., Lantzsch H.-J., Mosenthin R., Schöner F.-J., Biesalski H.K., Drochner W., 2002. Comparative evaluation of the efficacy of cereal and microbial phytases in growing pigs fed diets with marginal phosphorus supply. J. Sci. Food Agr. 82, 1298-1304 